\title{
ASSESSMENT OF MOTION RANGES OF KNEE AND ANKLE JOINTS OF THE AFFECTED LIMBS IN PATIENTS WITH HEMIPARESIS AFTER CEREBROVASCULAR ACCIDENTS
}

\author{
OCENA ZAKRESU RUCHOMOŚCI STAWU KOLANOWEGO I SKOKOWEGO \\ KOŃCZYNY NIEDOWŁADNEJ U CHORYCH Z NIEDOWŁADEM POŁOWICZNYM \\ PO INCYDENTACH MÓZGOWO-NACZYNIOWYCH
}

\author{
${ }^{1}$ Faculty of Physical Education and Health Promotion, University of Szczecin, Poland \\ ${ }^{2}$ Medical Clinic Spondylus, Szczecin, Poland \\ ${ }^{3}$ Department of Humanities in Medicine, Faculty of Health Sciences, \\ Pomeranian Medical University in Szczecin, Poland
}

S u m m a r y

B a c k g r o u n d. Cerebrovascular accident (stroke) is one of the most serious health problems in the developed countries. Patients who conclude early stroke rehabilitation (i.e. 2-3 months after the stroke) should be able to walk unassisted or with little help.

$\mathrm{O} \mathrm{b} \mathrm{j} \mathrm{e} \mathrm{c} \mathrm{t} \mathrm{i} \mathrm{v} \mathrm{e.} \mathrm{The} \mathrm{aim} \mathrm{of} \mathrm{this} \mathrm{paper} \mathrm{is} \mathrm{to} \mathrm{analyze} \mathrm{the}$ effectiveness of early specialized stroke rehabilitation by means of proprioceptive neuromuscular facilitation (PNF), based on the analysis of mobility ranges of knee and ankle joints of the affected limbs in patients after CVA.

M a t e ri a l a nd meth od s. The study encompassed 30 subjects who had suffered from stroke and participated in PNF rehabilitation at the hospital stroke ward. Among subjects, there were 13 men and 17 women, aged \pm 66.1 . On average, patients spent 28 days at the ward. The first exam was carried out prior to rehabilitation, on the admission day, while the follow-up exam was conducted on the day the patient left the ward.

$\mathrm{R}$ e s u $1 \mathrm{ts}$. Noticeable reduction of deficits in knee and ankle joint motion of the affected limb was observed. The second exam proved significant increase in bending ranges of the affected limb. Range of limb strengthening did not change. Subjects with left-sided hemiparesis displayed greater mobility deficits in motion ranges of knee and ankle joints, compared to right-sided hemiparesis patients.

$\mathrm{C}$ o $\mathrm{n} \mathrm{c} \mathrm{l} \mathrm{u} \mathrm{s}$ i o $\mathrm{n} \mathrm{s}$. Using PNF in early rehabilitation noticeably improved mobility of the affected limbs in patients after CVA.
W s t ę p. Udar mózgu jest jednym z najpoważniejszych problemów zdrowotnych społeczeństw z krajów uprzemysłowionych. Chory kończący wczesną rehabilitację poudarową, czyli 2-3 miesiące od udaru powinien chodzić samodzielnie lub z niewielką pomocą.

C e 1 e m p r a c y była analiza skuteczności wczesnej specjalistycznej rehabilitacji poudarowej, realizowanej metoda PNF, w oparciu o analizę zakresu ruchomości stawu kolanowego i skokowego kończyny niedowładnej u osób po mózgowym incydencie naczyniowym.
M a t e r i a 1 i m e t o d y. Badaniem objęto 30 osób po mózgowym incydencie naczyniowym poddanych wczesnej rehabilitacji metodą PNF na pododdziale udarowym. Grupę badawczą stanowiło 13 mężczyzn i 17 kobiet, o średniej wieku $\pm 66,1$. Czas przebywania chorego na oddziale wynosił średnio 28 dni. Pierwsze badanie wykonano przed rozpoczęciem usprawniania $\mathrm{w}$ dniu przyjęcia chorego, a kontrolne w dniu wypisu z oddziału udarowego.

W y n i k i. Stwierdzono wyraźną redukcję deficytów w stawie kolanowym i skokowym kończyny niedowładnej. 
W badaniu drugim wykazano znaczny wzrost zakresu ruchu zginania w kończynie niedowładnej. Wartość ruchu wyprostu pozostała bez zmian. Grupa chorych $\mathrm{z}$ niedowładem lewostronnym charakteryzowała się znacznie większymi ograniczeniami zakresów poszczególnych ruchów czynnych stawu kolanowego oraz skokowego górnego i dolnego niż grupa chorych z niedowładem prawostronnym.

W n i o s k i. Stosowanie metody PNF we wczesnej rehabilitacji wyraźnie usprawniło funkcjonowanie kończyny niedowładnej chorych po przebytym mózgowym incydencie naczyniowym.

Key words: cerebrovascular accident, CVA, stroke, early stroke rehabilitation, PNF, paresis

Stowa kluczowe: udar mózgu, wczesna rehabilitacja poudarowa, metoda PNF, niedowład

\section{INTRODUCTION}

Cerebrovascular accident (CVA) is one of the most serious health problems in the developed countries. Every year 15 million people suffer from stroke; approximately 5 million of them die within the next few days, while another 5 million remain inactive [1]. Demographic data and epidemiologic estimates suggest that the number of strokes in Europe will increase and reach 1.5 million in 2025, assuming no changes in incidence [2]. Stroke incidence rate in Poland is similar to the rates of other European countries. According to estimates, there are approximately 60,000 strokes per year in Poland [3]. It is mainly caused by increased proportion of the $65+$ age group, which is most prone to strokes. It is estimated that in 2050 proportion of this age group will reach $35 \%$ in the European Union; therefore, the number of strokes will gradually increase [4]. Despite significant advance in diagnostics, treatment and care provision, stroke is still associated with high risk of patient death. It is the third most common death cause in the world [5], forth in Poland [6] and the main cause of severe and chronic disability, which results in social and economic difficulties [7, 8].

One of the key factors that determine the recovery of patients is early start of rehabilitation. Despite some differences in terms of rehabilitation approaches, most experts agree that rehabilitation should start as soon as possible and continued in specialist centers, provided patient's overall state allows it and there are no counter indications [7-11]. Comprehensive therapy and rehabilitation should be provided to all patients, so that it can fully help each one of them [7, 12]. Early rehabilitation prevents consequences of long immobility, which poses a threat to life and health of patients, while also improving their quality of life [7-9, 13]. It should address mobility deficit and higher nervous activities $[7,10,14]$. It is equally important to provide diagnostics and rehabilitation of speech disorders [15]. The most important post-stroke rehabilitation instructions may be found in guidelines updated by the European Stroke Initiative (ESO) [16,
17] and Polish guidelines, developed by the Section of Vascular Diseases of the Polish Society of Neurology [18]. Current literature on the subject-matter prove that the best period to obtain functional improvement after the stroke are the first 3 months following CVA [19]. Unconscious patients are treated with passive exercises, while conscious patients are engaged in active, slow and supported workout [20]. Post-stroke rehabilitation success is measured by ability and quality of independent walk; therefore, key importance should be given to improving balance and stimulating the ability to walk [12].

The aim of this paper is to analyze the effectiveness of early specialized post-stroke rehabilitation, based on the analysis of motion ranges of knee and ankle joints of the affected limbs in patients after CVA.

\section{MATERIALS AND METHODS}

The study was conducted among stroke patients admitted to the Regional Hospital in Kołobrzeg, Poland, to a stroke ward, with a high dependency unit, which provided care for stroke patients based on the latest medical standards. The study was open to patients with hemiparesis, provided a stable overall condition. The group was 30-strong and included 13 men and 17 women. Right-sided hemiparesis was observed in $56.7 \%(n=17)$ of patients, while $43.3 \%$ $(n=13)$ suffered from left-sided hemiparesis. Subjects were divided into two groups, based on the side affected by CVA. Group A included right-sided hemiparesis patients, while Group B was made of leftsided hemiparesis subjects. $53.3 \%$ of subjects suffered from ischemic strokes, $40 \%$ of them from transient ischemic attack, and $6.7 \%$ from embolic stroke. The average age of subjects was \pm 66.1 (from 34 to 85 ). Patients spent on average 28 days at the ward.

Study program was described in the paper of Łubkowska et al. [21], which presented Part I of the results of author's own study on measuring active and 
Table I. Passive motion ranges of knee joint in Groups A and B in Exams I and II

Tabela I. Charakterystyka zakresów ruchów biernych $w$ stawie kolanowym w badaniu I i II w grupie A i B

\begin{tabular}{|c|c|c|c|c|c|c|c|c|c|c|c|c|c|c|}
\hline \multirow{4}{*}{ MOTION } & \multicolumn{7}{|c|}{ Examination I/ Badanie I } & \multicolumn{7}{|c|}{ Examination II/ Badanie II } \\
\hline & \multicolumn{6}{|c|}{ motion range $\left[\right.$ in $\left.^{\circ}\right] /$ zakres ruchu $\left[\mathrm{w}^{\circ}\right]$} & \multirow{3}{*}{$\mathrm{t} 1$} & & tion ran & [in $\left.{ }^{\circ}\right] /$ & zakres r & Ichu $[\mathrm{w}$ & & \multirow{3}{*}{$\mathrm{t} 2$} \\
\hline & \multicolumn{3}{|c|}{$\begin{array}{c}\text { affected limb } \\
\text { kończyna niedowładna }\end{array}$} & \multicolumn{3}{|c|}{$\begin{array}{c}\text { healthy limb } \\
\text { kończyna zdrowa }\end{array}$} & & \multicolumn{3}{|c|}{$\begin{array}{c}\text { affected limb } \\
\text { kończyna niedowładna }\end{array}$} & \multicolumn{3}{|c|}{$\begin{array}{c}\text { healthy limb } \\
\text { kończyna zdrowa }\end{array}$} & \\
\hline & Mean & SD & Vs & Mean & SD & Vs & & Mean & SD & Vs & Mean & SD & Vs & \\
\hline \multicolumn{15}{|c|}{ Group A/ Grupa A } \\
\hline Bending/Zgięcie & 117.1 & 7.72 & 6.59 & 117.2 & 7.66 & 6.54 & $0.022 \mathrm{~ns}$. & 119.8 & 6.95 & 5.89 & 117.9 & 6.77 & 5.74 & $-0.360 \mathrm{~ns}$. \\
\hline $\begin{array}{l}\text { Strengthening } \\
\text { Wyprost }\end{array}$ & 0 & 0 & 0 & 0 & 0 & 0 & 0 & 0 & 0 & 0 & 0 & 0 & 0 & 0 \\
\hline \multicolumn{15}{|c|}{ Group B/ Grupa B } \\
\hline Bending/Zgięcie & 112.0 & 5.42 & 4.63 & 112.0 & 5.88 & 5.25 & $0.000 \mathrm{~ns}$. & 113.6 & 4.67 & 4.11 & 113.0 & 4.97 & 4.11 & $-0.365 \mathrm{~ns}$. \\
\hline $\begin{array}{l}\text { Strengthening } \\
\text { Wyprost }\end{array}$ & 0 & 0 & 0 & 0 & 0 & 0 & 0 & 0 & 0 & 0 & 0 & 0 & 0 & 0 \\
\hline
\end{tabular}

n.s. difference statistically not significant $(\lambda=0.05)$

Mean - arithmetic mean value; SD - standard deviation; Vs - Variation coefficient.

t1 - Significance of differences between affected and healthy limb in Examination I;

t2 - Significance of differences between affected and healthy limb in Examination II

Table II. Active motion ranges of knee joint in Groups A and B in Exams I and II

Tabela II. Charakterystyka zakresów ruchów czynnych w stawie kolanowym w badaniu I i II w grupie A i B

\begin{tabular}{|c|c|c|c|c|c|c|c|c|c|c|c|c|c|c|c|}
\hline \multirow{4}{*}{ MOTION } & \multicolumn{7}{|c|}{ Examination I/ Badanie I } & \multicolumn{7}{|c|}{ Examination II/ Badanie II } & \multirow{4}{*}{$\mathrm{t} 3$} \\
\hline & \multicolumn{6}{|c|}{ motion range $\left[\right.$ in $\left.^{\circ}\right] /$ zakres ruchu $\left[\mathrm{w}^{\circ}\right]$} & \multirow{3}{*}{$\mathrm{t} 1$} & $\operatorname{mot}$ & ion rang & e $\left[\right.$ in $\left.^{\circ}\right] /$ & Zakres 1 & ichu [y & & \multirow{3}{*}{$\mathrm{t} 2$} & \\
\hline & \multicolumn{3}{|c|}{$\begin{array}{c}\text { affected limb } \\
\text { kończyna } \\
\text { niedowładna }\end{array}$} & \multicolumn{3}{|c|}{$\begin{array}{c}\text { healthy limb } \\
\text { kończyna zdrowa }\end{array}$} & & \multicolumn{3}{|c|}{$\begin{array}{l}\text { affected limb } \\
\text { kończyna } \\
\text { niedowładna }\end{array}$} & \multicolumn{3}{|c|}{$\begin{array}{c}\text { healthy limb } \\
\text { kończyna zdrowa }\end{array}$} & & \\
\hline & Mean & SD & Vs & Mean & SD & Vs & & Mean & SD & Vs & Mean & SD & Vs & & \\
\hline \multicolumn{16}{|c|}{ Group A/ Grupa A } \\
\hline Bending/Zgięcie & 31.9 & 6.75 & 21.14 & 11.44 & 7.4 & 6.47 & $92.91 *$ & 66.1 & 16.83 & 25.45 & 114.9 & 6.97 & 6.06 & $11.55^{*}$ & $12.27 *$ \\
\hline $\begin{array}{l}\text { Strengthening } \\
\text { Wyprost }\end{array}$ & 0 & 0 & 0 & 0 & 0 & 0 & 0 & 0 & 0 & 0 & 0 & 0 & 0 & 0 & 0 \\
\hline \multicolumn{16}{|c|}{ Group B/ Grupa B } \\
\hline Bending/Zgięcie & 18.9 & 8.43 & 44.7 & 109.1 & 5.53 & 5.1 & $31.00^{*}$ & 39.5 & 13.85 & 35.1 & 109.9 & 4.54 & 4.4 & $16.63^{*}$ & $10.84^{*}$ \\
\hline $\begin{array}{l}\text { Strengthening } \\
\text { Wyprost }\end{array}$ & 0 & 0 & 0 & 0 & 0 & 0 & 0 & 0 & 0 & 0 & 0 & 0 & 0 & 0 & 0 \\
\hline
\end{tabular}

*Statistically significant differences $(\lambda=0.05)$

Mean - arithmetic mean value; SD - standard deviation; Vs - Variation coefficient.

$\mathrm{t} 1$ - Significance of differences between affected and healthy limb in Examination I;

$\mathrm{t} 2$ - Significance of differences between affected and healthy limb in Examination II;

t3 - Significance of mean differences between affected limbs in Examinations I and II.

passive motion ranges in hip joints of the affected and unaffected lower limbs. Rehabilitation process employed the Proprioceptive Neuromuscular Facilitation method. All measurement used in the study were carried out twice: the first exam was held before rehabilitation started, on the admission day (Exam I), while the follow-up exam was conducted on the day when the patient left the ward (Exam II).

To analyze the data statistically, descriptive statistics methods were used (arithmetic mean, standard deviation, coefficient of variation). Hypotheses on significance of mean deviations for individual motion ranges were verified with statistical tests: Student's t-distribution for two means and Student's t-distribution for differences between correlated pairs.

\section{RESULTS}

Passive motion ranges of knee joint in affected and unaffected limbs in Groups A and B and Exams I and II are presented in Table 1. Data analysis showed that patients with right-sided hemiparesis (Group A) and left-sided hemiparesis (Group B) had similar average measurements, and the differences were not statistically significant.

Table 2 presents active motion ranges of the knee joint of the affected and unaffected limb in patients with right-sided hemiparesis (Group A) and left-sided hemiparesis (Group B) in Exams I and II. It was determined that the right-sided hemiparesis patients (Group A) displayed deficit of active bending motion, which equaled on average $25 \%$ of the physiological range. There were no deficits in straightening motion range. The differences were statistically significant. Exam II proved significant increase in bending ranges 
Table III. Active motion ranges of ankle mortise and ankle tarsus in Groups A in Exams I and II

Tabela III. Charakterystyka zakresów ruchów czynnych w stawie skokowym górnym i dolnym w badaniu I i II w grupie A

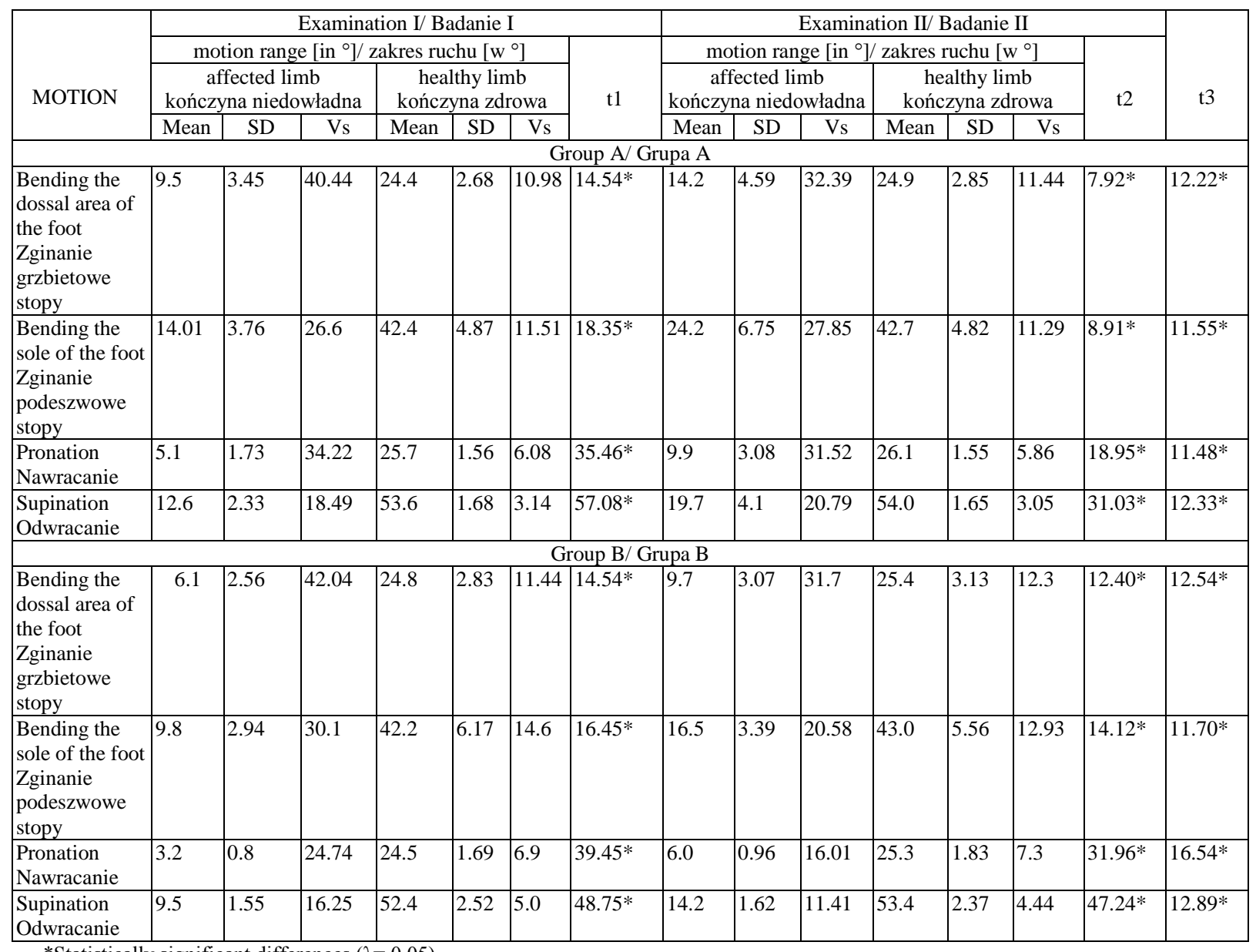

*Statistically significant differences $(\lambda=0.05)$.

Mean - arithmetic mean value; SD - standard deviation; Vs - Variation coefficient.

t1 - Significance of differences between affected and healthy limb in Examination I;

$\mathrm{t} 2$ - Significance of differences between affected and healthy limb in Examination II;

t3 - Significance of mean differences between affected limbs in Examinations I and II.

of the affected limb, which increased to $51 \%$ of the physiological range. Range of strengthening the limb did not change (differences were statistically significant). Exam I of Group B patients (left-sided hemiparesis) revealed significant deficits in bending motion in the affected limb. It equaled to only $15 \%$ of the physiological range. There were no deficits in straightening motion range. These values were statistically significant. Exam II proved significant increase in bending ranges of the affected limbs. It reached $30 \%$ of the physiological range. Range of limb strengthening did not change. These values were statistically significant. Percentage analysis of active motion ranges in the knee joint in Group A and B in Exams I and II showed that left-sided hemiparesis patients (B) had greater motion deficits in terms of bending the knee joint, compared to right-sided hemiparesis patients (A). Exam II showed also that despite improving the bending motion in the knee joint in both groups, the difference was still noticeable. The straightening motion in both groups in Exams I and II did not exhibit signs of deficits.

Table 3 presents active motion ranges of ankle mortise and ankle tarsus of the affected and unaffected limb in Exams I and II in Groups A and B. The analysis of data from Exam I and II indicated a noticeable improvement in active motion range of ankle mortise and ankle tarsus of the affected limb. The improvement was observed both in left-sided and right-sided hemiparesis (A and B) and was statistically significant. Exam I revealed very significant deficits in active motion range of the affected limb. Active motion of ankle mortise and ankle tarsus reached on average $23 \%$ of physiological values. The smallest deficits were observed in terms of bending the dorsal area of the foot and supination, while the biggest limitations were noticed during bending the foot sole and pronation. These values were statistically 
significant. The analysis of data from Exam II revealed an increase in active motion ranges in the affected limb. Nevertheless, they were still limited in comparison with the unaffected limb. It reached only $38 \%$ of the physiological range. The analysis of data from Exam I and II indicated a statistically significant increase in active motion range of ankle mortise and ankle tarsus of the affected limb. The percentage analysis based on Exams I and II of the active motion ranges in ankle mortise and ankle tarsus of the affected limb in Groups A and B showed that left-sided hemiparesis patients (B) had significantly more limited motion ranges of ankle mortise and ankle tarsus, compared the right-sided hemiparesis patients (A). Exam II also revealed that despite an increase in active motion range of ankle mortise and ankle tarsus in both groups during the rehabilitation process, the difference in motion ranges observed in Exam I did not disappear.

\section{DISCUSSION}

CVA causes many complications which may lead to death. Over a half of men and women aged below 65 , who suffer from stroke, die within 8 years [22]. 6 months after the stroke, half of patients still suffer from hemiparesis, every fifth patient cannot walk unassisted, many of them need help in everyday activities and suffer from aphasia, while 1/3 display symptoms of depression [22]. CVA forces the patients to re-learn their lost functions. Therefore, it is crucial to provide comprehensive, holistic hospital and non-hospital care, focused on extensive rehabilitation process [23]. Given current medical advances, the role of early, continuous and complex rehabilitation is indisputable $[6,7,8,11]$.

Author's own study conducted among 30 patients who suffered from CVA were aimed at analyzing the effectiveness of early specialized stroke rehabilitation, based on the analysis of motion ranges of knee and ankle joints of the affected limbs. The study indicated that early physiotherapy with PNF method helped to improve motion range parameters. Noticeable reduction of deficits in mobility of the knee and ankle joint of the affected limb was observed. Authors' previous study [21] revealed that early rehabilitation combined with PNF method significantly reduced disability level of stroke patients by increasing their active motion ranges and maintaining passive motion ranges in hip joints of the affected limb. Research suggests that $80 \%$ of patients re-learn to walk successfully; therefore, this skill should be treated as a priority in stroke rehabilitation programs [12, 24]. PNF method is a comprehensive therapeutic method, and one of the most commonly used worldwide. PNF is effective in treating various function losses [25]. Mazurowski et al.'s study [26] showed that using PNF to rehabilitate stroke patients at an early stage improves their balance and unassisted locomotion skills, and the results are not gender-dependent. Similarly, other authors' studies [27, 28, 29] indicated positive results of the PNF method.

In this paper and in the previous research [21], an analysis of PNF results (left- and right-sided hemiparesis) was conducted. All CVA patients displayed improved motion ranges of the hip joint, knee joint and ankle joint of the affected limb; however, greater progress was observed in right-sided hemiparesis patients. Mazurowski et al. [25] carried out a study on effectiveness of PNF by analyzing walking function and static and dynamic balance, as well as posture control in stroke patients. They observed an improvement in balance parameters, with the best results obtained by women with right-sided hemiparesis. Among men with left- and right-sided hemiparesis, values before and after rehabilitation were similar [25]. Krukowska and Czernicki [30] observed in their study a greater improvement in patients with right-sided hemiparesis.

The study revealed that a 28-day rehabilitation period was insufficient to obtain full active motion range in the affected limb. Patients still suffered from limited motion range in lower limb joints and required further physiotherapy to regain functionality. Rehabilitating process that starts at the stroke ward should be professionally continued at neurological rehabilitation ward, where early stroke rehabilitation is offered; it should take 3-9 weeks. Continuation of the therapy should focus on improving walking, position changes and further stimulation of functions. Patients who finish early post-stroke rehabilitation (i.e. 2-3 months after the stroke) should be able to walk unassisted or with little help [21]. 'Aggressive rehabilitation' should be the main component, i.e. focusing on physical activity [22]. Meanwhile in Poland, patients face shortage of rehabilitation beds; patients are often sent home with a list of recommendation which are often difficult to fulfill. Thus, comprehensive rehabilitation process and its availability seems to be the top priority. Unfortunately, Mazurowski et al.'s study [10] showed that only a small proportion of neurology (14\%) and rehabilitation 
$(10 \%)$ wards in Poland offer comprehensive stroke rehabilitation.

\section{CONCLUSIONS}

The analysis of results obtain in exams carried out at the beginning and end of the rehabilitation process among stroke patients led the following conclusions:

1. PNF rehabilitation method improved active motion parameters and helped to maintain passive motion ranges in knee and ankle joints of the affected limb in hemiparesis patients, who participated in early physiotherapy.

2. PNF in early rehabilitation noticeably improved mobility of the affected limb in patients with CVA.

3. Significantly better results of affected limb rehabilitating were observed in right-sided hemiparesis patients.

4. 4-week rehabilitation period was insufficient to obtain full active motion range in the affected limb. Patients still required further physiotherapy to regain functionality.

\section{REFERENCES}

1. Wolfe C.D.A., Crichton S.L., Heuschmann P.U., et al. Estimates of Outcomes Up to Ten Years after Stroke: Analysis from the Prospective South London Stroke Register. PLoS Med. 2011; 8(5): e1001033. DOI:10.1371/journal.pmed.1001033

2. Truelsen T., Piechowski-Jóźwiak B., Bonita R., et al. Stroke incidence and prevalence in Europe: a review of available data. Eur J Neurol. 2006;13(6): 581-598. DOI: 10.1111/j.1468-1331.2006.01138.x

3. Członkowska A., Ryglewicz D. Epidemiology of cerebrovascular accidents in Poland. Neurol Neurochir Pol. 1999; 32(6): 99-103.

4. Grabowska-Fudala B., Jaracz K., Górna K. Stroke incidence, case fatality and mortality - current trends and future prognosis. Przegl Epidemiol. 2010; 64(3): 439-42.

5. Wolfe C.D.A. The impact of stroke. Br Med Bull. 2000; 56(2): 275-286.

6. Grochulska A., Jastrzębska M. Improvement in functional performance of people suffering from brain stroke - the role of a nurse. Probl Pielęg. 2012; 20(3): 300-309.

7. Kwolek A., Szydełko M., Domka E. The limits of contraindications to post-stroke rehabilitation. Udar Mózgu. 2005; 7(1): 31-37.

8. Piskorz J., Wójcik G., Iłzecka J., et al. Early post-stroke rehabilitation in patients with cerebral infarction. [Article in Polish]. Med. Og Nauk Zdr. 2014; 20(4): 351-355.
9. Pasek J., Opara J., Pasek T., Sieroń A. Activities of daily living depending on subtype of ischaemic stroke and early rehabilitation. Udar Mózgu. 2009; 11(2): 41 49.

10. Członkowska A., Sarzyńska-Długosz I., Krawczyk M. An evaluation of the accessibility of early post-stroke comprehensive rehabilitation in Poland. Neurol Neuroch Pol. 2006; 40(1): 10-15.

11. Wiszniewska M., Kobayashi A., Członkowska A. Cerebrovascular Accident treatment. Summary of Guidelines by Vascular Disease Experts from the Polish Neurology Association, 2012. [Article in Polish]. Pol Prz Neurol. 2012; 8(4): 161-175.

12. Flis D., Bejer A. The influence of chosen clinical and demografic factors on progress in reeducation of balance and walk of people after stroke. Adv Rehabil 2013; 27(4): 31-39. DOI: 10.2478/rehab-2014-0024

13. Muren M.A., Hütler M., Hooper J. Functional capacity and health-related quality of life in individuals post stroke. Top Stroke Rehabil 2008; 15(1): 51-58. DOI: 10.1310/tsr1501-51

14. Członkowska A. Cerebrovascular accidents - treatments available in Poland in the light of global advances. [Article in Polish]. Pol Prz Neurol. 2005; 1(1): 1-7.

15. Karakiewicz B., Żułtak-Bączkowska K., Mroczek B. Modern ways of therapy and rehabilitation of disabled persons - computer supported rehabilitation of cognitive functions among patients after neurological problems. Przew Lek. 2011; 1: 231-234.

16. The European Stroke Organisation (ESO) Executive Committee and the ESO Writing Committee. Guidelines for Management of Ischeamic Stroke and Transient Ischaemic Attack 2008. Cerebrovasc Dis. 2008; 25: 457-507. DOI: 10.1159/000131083

17. Treatment of cerebral infarction and transient ischemic attack. European Stroke Organization guidelines, 2008. [Article in Polish]. Medycyna Praktyczna - Wydanie specjalne 2009; 1: 41-45.

18. Guidelines by Vascular Disease Experts from the Polish Neurology Association. Post-stroke rehabilitation in Cerebrovascular Accident treatment. [Article in Polish]. Neurol Neurochir Pol. 2012; 46(1(supl. 1)).

19. Ziejka K., Skrzypek-Czerko M., Karłowicz A. The Importance of Stroke Rehabilitation to Improve the Functional Status of Patients with Ischemic Stroke. J Neurol Neurosur Nursing. 2015; 4(4):178-183. DOI: 10.15225/PNN.2015.4.4.6

20. Morris P.E., Goad A., Thompson C., et al. Early intensive care unit mobility therapy in the treatment of acute respiratory failure. Crit Care Med. 2008; 36(8): 2238-2243. DOI: 10.1097/CCM.0b013e318180b90e

21. Łubkowska W., Zdeb T., Mroczek B. Assessment of Impact of Early Stroke Rehabilitation on Hip Joint Mobility of the Affected Leg in Patients after Cerebrovascular Accidents. Cent Eur J Sport Sci Med. 2015; 12(4): 17-23. DOI: 10.18276/cej.2015.4-02

22. American Heart Association. Heart Disease and Stroke Statistics - 2003 Update. Dallas, Tex: American Heart 
Association;

2002.

DOI: 10.1161/01.STR.0000127303.19261.19

23. Mazurek J, Blaszkowska A, Rymaszewska J. Rehabilitation after stroke - current guidelines. Now Lek. 2013; 82(1): 83-88.

24. Czernuszenko A. Community rehabilitation after stroke. Reh Med. 2011; 15(2): 15-20.

25. Kwiecień-Jaguś K., Zwoliński T., Szamotulska J. Early stages of rehabilitation in the intensive care unit using the method of Proprioceptive Neuromuscular Facilitation (PNF). Anest Ratow. 2016; 10: 86-96.

26. Mazurowski P., Knyszyńska A., Lubkowska A. The method of Proprioceptive Neuromuscular Paving the Movement in the early rehabilitation after stroke. Med Health Sci Rev. 2015; 1(4): 21-30.

27. Hess D.R. Patient positioning and ventilator-associated pneumonia. Respire Care. 2005; 50(7): 892-8.

28. Rajiv S., Ravinder N., Shiv K. Comparison of proprioceptive neuromuscular facilitation vs resistance training of respiratory muscles on respiratory rate of patients in ICU during weaning off period. Indian $\mathbf{J}$ Physiother Occup Ther. 2010; 4(4): 125-8.

29. Kaniewski O., Suszyński K., Górka D., et al. Effect of PNF-therapy on recovery in patients after ischemic stroke located in left hemisphere in acute rehabilitation. Ann Acad Med Siles. 2014; 68(5): 294-301.

30. Krukowska J., Czernicki J.: The stabilometric evaluation of the impact of neurophysiological physical methods on balance improvement in patients after a stroke. Reh Med. 2012; 16(2): 16-21.
31. Kaniewski O., Suszyński K., Górka D., et al. Effect of PNF-therapy on recovery in patients after ischemic stroke located in left hemisphere in acute rehabilitation. Ann Acad Med Siles. 2014; 68(5): 294-301.

32. Krukowska J., Czernicki J.: The stabilometric evaluation of the impact of neurophysiological physical methods on balance improvement in patients after a stroke. Reh Med. 2012; 16(2): 16-21.

\section{Address for correspondence:}

Wioletta Łubkowska, $\mathrm{PhD}$

University of Szczecin

Faculty of Physical Education and Health Promotion

Al. Piastów 40B, building 6

71-065 Szczecin

Poland

tel.: + 48 tel: $(+48) 9144427$ 79/ -49

fax: (+48) 914442736

e-mail: wioletta.lubkowska@univ.szczecin.pl

Received: 20.07.2016

Accepted for publication: 12.08.2016 